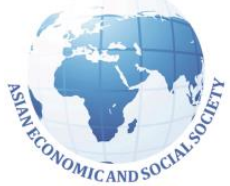

AESS

\section{Asian Journal of Empirical Research}

http://aessweb.com/journal-detail.php?id=5004 DOI: $10.18488 /$ journal.1007/2016.6.4/1007.4.84.100

\title{
EFFECT OF BOARD'S SKILLS ON STAKEHOLDER VALUE
}

\author{
Ines Chaabouni \\ Assistant professor; Imam Muhamed Ben Saud Islamic University, Riyadh, Saudi Arabia \\ Anis Jarboui \\ Professor; Sfax University, Tunisia
}

\section{Article History: \\ Received: 23-May-2016 \\ Revised received: $18-\mathrm{July}-$ 2016 \\ Accepted: 25-July-2016 \\ Online available: 20 -August- 2016}

\section{Keywords:}

Board's cognitive function, board's skills, value creation

\begin{abstract}
The aim of this paper is to discuss the effect of the board's capital on the firm value by the intermediation of the board's functions. We took a sample of 73 Tunisian public limited companies and we tested the direct impact of the board's functions on the firm value and its mediator role on the relationship between board's capital and firm's value by using structural equations. Our results show that only the board's cognitive function has an impact on shareholder and stakeholder value. In fact, the board's disciplinary function loses its signification by integrating the skills and competencies of directors. Moreover, the board's cognitive function plays a mediator role between the board's capital and the firm's value. Our study aims to stress the new role of the board of directors as a provider of skills and expertise that can ameliorate the value of the firm by assisting the manager in making adequate decisions.
\end{abstract}

\section{INTRODUCTION}

The interest given to corporate governance is explained by its close relationship to the process of value creation. Indeed, the results of several studies (Albouy, 1999; Mitton, 2002; Lemmon et al., 2003; Brown \& Caylor, 2006; Black et al., 2006; Kowalwiski, 2012; Monda \& Giorgino, 2013) indicate that better governed firms are more profitable and pay more dividends to their shareholders. Black (2001) adds that the effect of governance mechanisms is more important in developing countries characterized by the weakness of their legal rules and the wide variation in the practice of governance mechanisms by companies.

The observation of studies on the interaction between governance mechanisms and firm performance shows that they are focused around a disciplinary perspective. Recent works add a cognitive dimension that highlights the central role of knowledge and skills of the partners of the firm to encourage the process of organizational learning and innovation (Charreaux, 2002; Jeanjean \& Stolowy, 2006). 
Overall, the literature on corporate governance recognizes that there is no ideal control mechanism. The effectiveness of these mechanisms in terms of value creation depends heavily on skills, expertise and networks of its stakeholders.

In the best of our knowledge, there is no published empirical paper that establishes the relationship between corporate governance mechanisms, and especially the board of directors' skills, and the firm value by using structural equations. We assume that the board's functions (disciplinary and cognitive) play a mediator role in the relationship between the board's capital and the firm's value. Hence, our research question addressed in this paper is intended to focus the researchers' interest on the competencies and networks of board's directors.

This paper is proceeds as follows: (i) section one presents a literature review concerning the effect of the board of directors on the firm value and develops hypotheses about the mediator role of the board's functions. (ii) Section two introduces our empirical models and describes data and variables measures. (iii) Section three will be oriented to present and interpret our results.

\section{LITERATURE REVIEW AND HYPOTHESES DEVELOPMENT}

\subsection{Impact of the director's board on firm value}

The impact of the board of directors on the firm performance has been the subject of several studies. To investigate this relationship, two currents are highlighted:

The first current which is the most dominant one is based on agency theory. It postulates that the function of the Board is limited to the management control of the executives and thus positively affects the value of the business by minimizing agency costs. These studies have focused on the impact of the traditional features of the board (its composition, its size and duality officer) on the value of the firm (Charreaux, 1997; Charreux, 2000; Walt, 2003; Carter et al., 2003).

The second current, relatively less explored, rests on the theory of resources dependence (Penrose, 1959) and gives administrators the role of advice and support of the leader. Thus, improving the performance of the firm is explained, according to Pfeffer and Salancik (1978), Zahra and Pearce (1989), Jhonson et al. (1993) and Rindova and Fumbrun (1999) by the advice and the provision of resources guaranteed by the board of directors.

However, Hillman and Dalziel (2003) criticize previous researches that they are studying a function of the Board (disciplinary or cognitive) at the expense of the other. These researches result in an incomplete understanding of the manner in which administrators assign the value of the firm. Indeed, in practice, the board controls and guides leaders in their strategic choices thus ameliorate the performance of the company. To do this, Hillman and Dalziel (2003) propose to integrate disciplinary and cognitive perspectives in one model to better understand the process of value creation in the company. So we can put our two hypotheses:

H1: Monitoring by the board of directors affects positively the firm value.

$\mathrm{H} 2$ : The cognitive role of the board of directors affects positively the firm value.

Moreover, the combination of these two theoretical perspectives, allows us to perceive that they have, as background, "the capital of the board," suggested by Hillman and Dalziel (2003) and Ioannis (2009).

\subsection{Impact of the board's capital on the firm value}

The capital of the board includes skills, cognitive inputs and external relations of directors. Although the theory of dependence on resources does not use this terminology, it discusses the expertise, knowledge, experience and reputation of directors defined as human capital. This theory adds the 
relational capital of the directors as a second type of Board's Capital and considered as a new determinant of the value of the company.

The Board Capital is positively associated with the provision of 5 benefits indicated by Pfeffer and Slancik (1978):

- The production of advice which Westphal (1999) associates directly to improve performance.

- The production of the legitimacy of the firm and its reputation. Firms with a prestigious Board of Directors are experienced and successful in takeover transactions.

- The production of a communication channel that facilitates the flow of information between the firm and its environment.

- The formulation of an effective future strategy through outreach directors and employees. In this context, Rosenstein and Wyatt (1997) show that shareholder value of the firm increases when its leader seat on the board of another firm.

- Assistance in the acquisition of external resources to the firm as the influence of financial capital and the influence of political parties or other important stakeholders.

In addition, Hillman and Dalziel (2003) distinguish between two types of Board Capital namely the social capital formed by the relationships of directors (Arrègle et al., 2004. Fadyen Mc, 2003 and Jhonson et al., 2013) and the human capital formed by the skills and knowledge of the members serving on the board of directors required for access to resources (Sicilianon, 1996) and to control the manager (Beekun et al., 1998).

\subsection{Hypothesis about the mediator role of Board functions on the relationship between Board Capital and firm Value}

The examination of the two functions of the Board (control and service) and their background is very important because the directors undertake more and more in both functions. Indeed, in a study of Korn (1999) on the time spent in the functions of the Board, the directors listed in a decreasing order, the time spent in different functions: identifying threats and opportunities for the future of the firm, monitoring and evaluating of implemented strategies, establishing external relations with large companies, evaluating and remunerating of the CEO and finally giving advice if important decisions, those concerning acquisition and merger, are taken. Hence, the integration of control functions and resource production not only reflects reality but it also leads to threats if we choose an approach and not the other.

Thus, we will study the effects of human and relational capital of directors on the value of the company through the mediation of the two functions of its Board.

Hypotheses about the mediator role of the disciplinary function on the relationship between the Board Capital and the firm Value

The impact of the Board capital on its control function was not explicitly discussed by the agency theory, however, Jensen and Meckling (1976) stated implicitly the importance of the skills of professionals in the effective control, by using the term "competitive advantage".

Carpenter and Westphal (2001) found that when the board has experience in a particular situation of the company or a specific expertise that allows them to better understand the work within the company, the control will become most effective. Thus, the skills, knowledge and experience of the Board positively affect the control over the manager and the evaluation of strategy.

H3: Disciplinary function of the Board has a mediator role on the relationship between the Board Capital and the firm value:

a. on the relationship between the human Capital and the shareholder value 
b. on the relationship between the human Capital and the stakeholder value

c. on the relationship between the relational Capital and the shareholder value

$d$. on the relationship between the relational Capital and the stakeholder value

Hypotheses about the mediator role of the cognitive function on the relationship between the Board Capital and the firm Value

Beyond the disciplinary role of the Board and its defining features that have been extensively studied theoretically and empirically, the cognitive dimension gives a new cognitive role to this governance mechanism. It undergoes an important development especially with the expansion of the network of administrators and their participation in making strategic business decisions.

According to an interview conducted by Berghe and Baelden (2005) with members of a board of directors, they concluded that directors need to have a vision of strategy formulation. Therefore, these members must be able to estimate the socio-political changes in the environment and understand its complexity and uncertainty. Moreover, studies on American and French companies have shown a significant proportion of boards considered actively engaged in the strategic options and $25 \%$ of the time of the board meetings is devoted to strategic issues. In the same vein, a member of the board said: "We need to be able to see this and keep an eye on the future."

By focusing on the cognitive function of the board, we can say that the first background of this function, widely discussed in the literature, is the board capital. The presence of directors with a strong relational activity in a board leads to an easy access to relevant information. Charreaux (2000) postulates, according to cognitive theory, outside directors are the main creators of new investment opportunities. They can help managers in detecting new productive opportunities.

Therefore, administrators produce, through a combination of mandates and their relational networks, social cognitive externalities helpful to the firm to assist in obtaining credits (Carpenter and Westphal, 2001) and to provide appropriate advice to the executive (Ben Hadj Barek, 2005).. Thus, skills and networks administrators have an indirect impact on the value of the firm through the intermediation of the cognitive function of the board. Hence, the hypothesis H4:

H4: Cognitive function of the Board plays a mediator role on the relationship between the Board Capital and the firm value:

a. on the relationship between the human Capital and the shareholder value

b. on the relationship between the human Capital and the stakeholder value

c. on the relationship between the relational Capital and the shareholder value

$d$. on the relationship between the relational Capital and the stakeholder value

\section{DATA AND METHODOLOGY}

Our goal is to study the impact of the board on the value of Tunisian public companies. Specifically, we will highlight the simultaneous relationship between the functions of board (disciplinary and cognitive) and shareholder and stakeholder value of these firms. The necessary information for this study was collected from the site of Tunisian Stock Exchange (TSE) and through the questionnaire distributed to managers of firms. In total we distributed, through email and via accountants, 123 questionnaires but we have received only 73 responses. Therefore, the final sample was composed of 73 companies which operate in various industries. It is noted finally that the various data are relating to the year 2010 .

We emphasize that our empirical study will include several types of variables: dependent variable (firm value), independent variables (Board Capital), mediator variables (functions of the Board of directors) and control variables. 


\subsection{Firm value}

The value of the company was perceived through shareholder value and stakeholder value. The use of stakeholder value has the advantage of taking into account the value provided by all stakeholders that has been neglected by shareholder value. Thus, our choice of measure is justified by the desire to compare these two types of measure of the value created.

\subsubsection{Shareholder value}

To measure shareholder value, several indicators have been advocated including the Return on Investment (ROI), Return on Equity (ROE) used by Abor and Biekpe (2006), Tobin's Q, the market value added (MVA) and the index of value creation.

In our study, we follow Ghaya and Lambert (2010) and we propose to use Tobin's Q as a measure of creating shareholder value. The advantage of this measure is that it takes into account the market value and the market value of the firm since it is measured by:

\section{Tobin's $Q=($ stock value + financial debts)/total assets}

\subsubsection{Stakeholder value}

Stakeholder value will be calculated by the following reflection of Poulain (2006). The latter, to measure stakeholder value, focused on the recipients of this value. Thus, for each company in our sample, we calculate the value perceived by each partner to know the value of employees, shareholders, lenders and the government.

Creating value for employees is measured by the share of value added absorbed by personnel costs and employee participation in profit-sharing.

To the lenders, value is measured by the value used to pay interest costs. In favor of the state, it is measured by the value used to pay taxes on income and profit tax. Finally, to shareholders it is measured by the value added in the form of dividends paid to shareholders.

Moreover, given the plurality of missing data on taxes and similar taxes we were unable to provide satisfactory measures of the value allocated to the state, so the definitive measures considered in this study are summarized in the table below:

Table 1: Measures of firm value

\begin{tabular}{|c|c|c|}
\hline Firm Value & Indicators & Measure \\
\hline Shareholder Value & Tobin's Q & $($ Stock value + financial debt)/total assets \\
\hline \multirow{4}{*}{ Stakeholder Value } & Added Value (AV) & $\begin{array}{l}\text { Turnover - Intermediate Consumption } \\
\text { (Personnel costs + participation of employees) / }\end{array}$ \\
\hline & $\begin{array}{l}\text { AV allocated to } \\
\text { employees }\end{array}$ & $\begin{array}{l}\text { AV } \\
\text { (Personnel costs + participation of employees) / } \\
\text { VA }\end{array}$ \\
\hline & $\begin{array}{l}\text { AV allocated to } \\
\text { Shareholders }\end{array}$ & Dividends/AV \\
\hline & $\begin{array}{l}\text { AV allocated to } \\
\text { lenders }\end{array}$ & Interests/AV \\
\hline
\end{tabular}

\subsection{Functions of the board}

Based on the work of Ben Hadj M'Bareck (2005) and Khlif and Karoui (2010), we tried to capture the disciplinary and cognitive functions of the Board of directors. For the first function, we have established a series of 6 questions (on a Likert scale with 5 points) on all areas of theoretical intervention of the Board for control and monitoring. The following table summarizes the items used to measure this variable. 
Table 2: Items measuring the disciplinary function of the board

\begin{tabular}{l} 
Items \\
\hline Administrators control the performance of the company \\
Administrators control the management team \\
Administrators control the decisions taken by the manager \\
Administrators control manager remuneration \\
Administrators control the appointment / removal of directors \\
Administrators control the appointment / removal of managers \\
\hline
\end{tabular}

For the cognitive function, we examined the involvement of directors in strategic decision-making and support the leader. To do this, we have implemented a series of 8 questions (on a Likert scale with 5 points) seeking to emphasize the cognitive and strategic roles of directors. All of these questions are presented in Table 3.

\section{Table 3: Items measuring Cognitive function of the Board}

\begin{tabular}{l} 
Items \\
\hline Directors help the manager to make strategic decisions \\
The directors of the company provide information on growth opportunities \\
The directors of the company provide information on other companies \\
Administrators provide advice. \\
This advice is based on their professional experience in other companies \\
The directors of the company are involved in solving management problems \\
The directors of the company are involved in the analysis of the external environment \\
The directors of the company follow the implementation of the strategy
\end{tabular}

\subsection{Capital of the board}

As already noted, the board has two types of capital: relational capital and human capital. To measure the human capital of the board, we have developed a series of 6 questions, measured on Likert scale with 5 points, trying to identify the different types of skills present in the board. This list was adapted from Ong and Wan (2005), and Karoui and Khlif work (2010) and the scale of Kula (2005).

\section{Table 4: Items measuring the human capital board}

\begin{tabular}{l} 
Items \\
\hline Degree of knowledge of the competitive environment by Board members \\
Level of knowledge of markets and customers of the company by the Board members \\
Degree of knowledge of foreign markets by Board members \\
Degree of knowledge of the products and services of the company by the Board members \\
Degree of knowledge of the organization of the company by the Board members \\
Degree of knowledge of the culture of the company by the Board members
\end{tabular}

Moreover, the relational capital of the board is measured by a series of 5 questions, measured on Likert scale with 5 points, highlighting the relational network administrators and their impact on financial decision making and the strategy of the firm.

\section{Table 5: Items measuring the relational capital board}

\begin{tabular}{l} 
Items \\
\hline To determine the ideal level of debt, administrators rely on the advice of their social relationships. \\
Administrators often provide intermediation with actors in the external environment \\
The relational network administrators help the company to receive more credit \\
The network administrators facilitate access to financial resources \\
Relationships allow administrators to have credit at a lower cost \\
\hline
\end{tabular}


We conducted an exploratory factor analysis on all the items used in this research. These constructs as we have stated, are from the literature. We ensure through principal component analysis (PCA) in SPSS that the measures are valid.

To ensure the reliability of measurements, some items have been removed. The table below summarizes the different items selected, the percentage of variance explained and Cronbach's alpha for each scale.

Table 6: Factorial analysis scales

\begin{tabular}{lccc}
\hline & Number of & \% of variance & Cronbach's \\
\hline Human Capital of BD & 3 & $69 \%$ & 0.801 \\
Relational Capital of BD & 4 & $71 \%$ & 0.867 \\
Disciplinary Function of BD & 3 & $74 \%$ & 0.777 \\
Cognitive Function of BD & 3 & $67 \%$ & 0.787 \\
\hline
\end{tabular}

\subsection{Control variables}

According to Thiétart (1999), the inclusion of control variables improves the degree of external validity of the results. In our study, the inclusion of control variables related to the characteristics of the board can influence its functions. In addition, we propose to incorporate the "debt level" variable as a control variable having a possible impact on the value of the company.

- $\quad$ CEO duality: Fosberg (1989), Abor and Biepke (2006), Khlif and Karoui (2010) and Bodaghi and Ahmadpour (2010) measured the combined functions of leadership and chairman by a binary variable taking 1 if the CEO is also chairman of the board and 0 otherwise. We adopt the same measure to test our models.

- Board Independence: This is a variable that measures the independence of the board. It is given by the percentage of board members qualified as independent directors. Although studies vary in their definitions of independent director (external), a set of criteria is common to all these definitions. In fact, we count as an independent director, the member who is not responsible in the company, or who has family relationship with leaders and more generally has no significant contractual relationship with the company (ElGaied and Rachhi, 2008).

- Board size: is given by the number of directors serving on the board of the company. This measure has been adopted by most researchers (Lipton and lorsch 1992; Berger et al., 1997, Anderson and Reeb, 2004, Biepke and Abor, 2006).

- Age range of directors: is measured by the number of directors in the board divided by age group (Jeanjean and Stowley, 2006).

- $\quad$ Bank shareholding: is measured by the proportion of capital held by the bank shareholder.

- Debt: is measured by total current and long term debts relative to the total assets. This measure has been adopted by several authors including Suhaila and Mahmood (2008), and Heng and Azrbajani (2012).

Our hypotheses will be tested in two stages:

- $\quad$ First, we consider a first global model to test hypotheses H1 and H2. We will integrate control variables, previously defined, in these models.

Next, we will discuss a second model to measure the mediating roles of Board functions (disciplinary and cognitive) on the relationship between Board Capital and the firm value. That concerns hypotheses $\mathrm{H} 3$ and $\mathrm{H} 4$.

Table 7: Testing hypotheses

\begin{tabular}{lll}
\hline & \multicolumn{1}{c}{ Hypotheses } & Model \\
\hline H1 and H2 & Links between Board functions and firm value & Model 1 \\
H3 and H4 & Mediator Role of Board functions & Model 2 \\
\hline
\end{tabular}


The software that we used to estimate the model is XLSTAT 2012 and more specifically PLSPM approach. We choose this software because it provides an indicator of the fit of the model goodness (Gof) which gives an assessment of the overall model.

\section{RESULTS}

\subsection{Results of Model 1: Links between the board functions and the firm value}

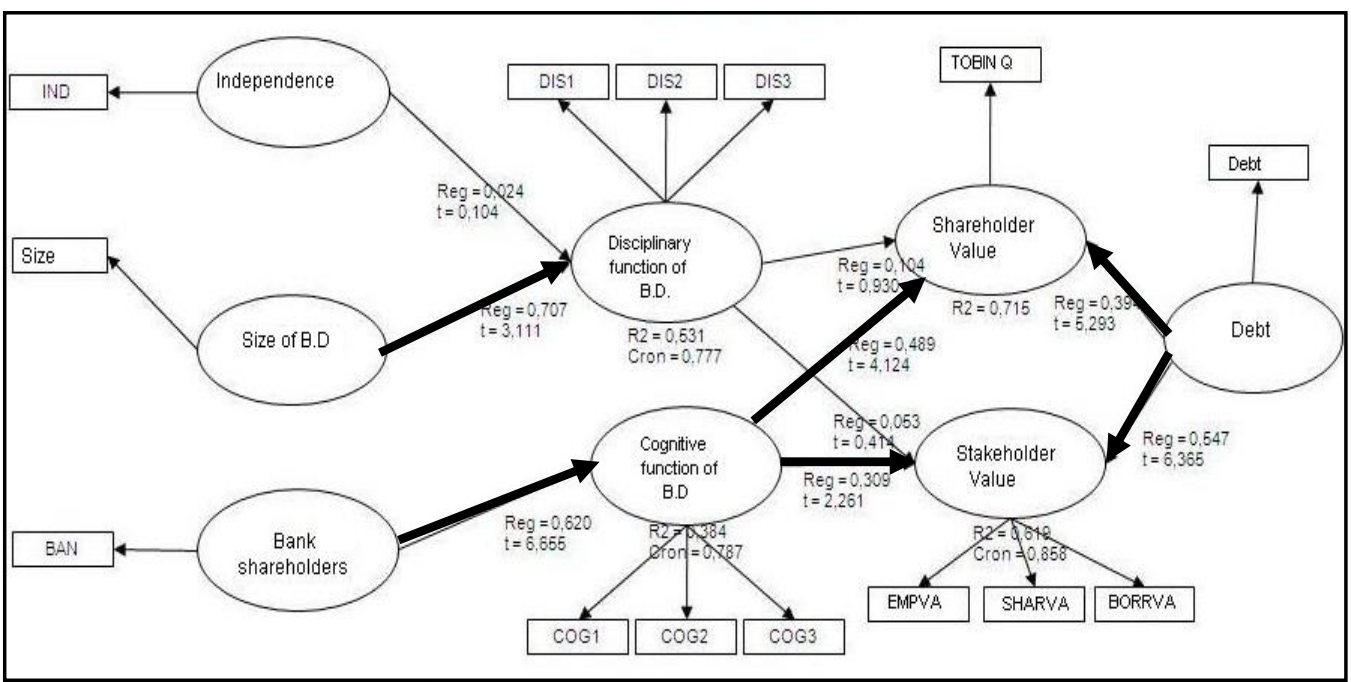

Figure 1: Results of model $1^{1}$

\subsubsection{Evaluation of the measurement Model (External Model)}

Table 8: Composite reliability

\begin{tabular}{lcccc}
\hline Latent Variable & $\begin{array}{c}\text { Cronbach's } \\
\text { Alpha }\end{array}$ & Rho DG & $\begin{array}{c}\text { First } \\
\text { eigenvalue }\end{array}$ & $\begin{array}{c}\text { Second } \\
\text { eigenvalue }\end{array}$ \\
\hline Disciplinary Function of BD & 0.777 & 0.881 & 2.216 & 0.525 \\
Cognitive Function of BD & 0.787 & 0.878 & 2.010 & 0.639 \\
Stakeholder Value & 0.858 & 0.918 & 2.375 & 0.371 \\
\hline
\end{tabular}

From Table 8, Cronbach's alphas, the Rhos Dillon and Goldestein are above 0.7 which indicates the reliability of the block variables. Note also that the first eigenvalue is greater than 1 , while the second is less than 1, for each latent variable which shows the unidimensionality of variables. So we have the right to use the reflective model (mode A). It should be noted that the indices do not appear to variables with a single manifest variable.

Table 9: Convergent and discriminant validity (AVE $>$ Squared correlation) ${ }^{2}$

\begin{tabular}{|c|c|c|c|c|c|c|c|c|}
\hline & $\begin{array}{l}\text { Size } \\
\text { BD }\end{array}$ & $\begin{array}{c}\text { Bank } \\
\text { shareholder }\end{array}$ & Indep & $\begin{array}{c}\text { Disciplinary } \\
\text { Function } \\
\text { BD } \\
\end{array}$ & $\begin{array}{c}\text { Cognitive } \\
\text { Function } \\
\text { BD } \\
\end{array}$ & Debt & $\begin{array}{c}\text { Shareholder } \\
\text { Value }\end{array}$ & $\begin{array}{c}\text { Stakeholder } \\
\text { Value }\end{array}$ \\
\hline \multicolumn{9}{|l|}{ Size BD } \\
\hline $\begin{array}{l}\text { Bank } \\
\text { shareholder }\end{array}$ & 0.644 & & & & & & & \\
\hline Independence & 0.870 & 0.824 & & & & & & \\
\hline Disciplinary & 0.531 & 0.279 & 0.467 & 0.681 & & & & \\
\hline
\end{tabular}

${ }^{1}$ Relations in bold are significant

${ }^{2}$ Values in bold on the diagonal correspond to the AVE associated with each latent variable, while the other values are squared correlations between manifest variables. 


\begin{tabular}{lllllllll}
\hline $\begin{array}{l}\text { Function } \\
\text { B.D }\end{array}$ & & & & & & & & \\
Cognitive & 0.702 & 0.384 & 0.623 & 0.669 & 0.712 & & \\
$\begin{array}{l}\text { Function B.D } \\
\text { Debt }\end{array}$ & 0.389 & 0.474 & 0.448 & 0.161 & 0.254 & & & \\
$\begin{array}{l}\text { Shareholder } \\
\text { Value }\end{array}$ & 0.891 & 0.873 & 0.948 & 0.438 & 0.596 & 0.465 & & \\
$\begin{array}{l}\text { Stakeholder } \\
\text { Value }\end{array}$ & 0.598 & 0.699 & 0.687 & 0.277 & 0.396 & 0.525 & 0.732 & 0.779 \\
\hline
\end{tabular}

The values of AVE are all above 0.5 , so it is a good convergent validity reflecting a strong correlation between the items that form the same building. The AVE is not displayed for variables with a single manifest variable.

In addition, the value of the AVE is always superior to the square correlations with other manifest variables demonstrating good discriminated validity. Items that measure different constructs are weakly correlated.

\subsubsection{Evaluation of structural model (Internal Model)}

In order to assess the structural model, we examine the paths coefficients and the $\mathrm{R}^{2}$ for each latent variable.

\section{Table 10: Structural Model}

\begin{tabular}{lcccccc}
\hline & $\mathbf{R}^{\mathbf{2}}$ & $\mathbf{F}$ & $\mathbf{P r}>\mathbf{F}$ & $\mathbf{R}^{\mathbf{2}}$ (Bootstrap) & $\begin{array}{c}\text { Standard } \\
\text { deviation }\end{array}$ & $\begin{array}{c}\text { Critical Ratio } \\
\text { (CR) }\end{array}$ \\
\hline $\begin{array}{l}\text { Disciplinary } \\
\begin{array}{l}\text { Function B.D } \\
\text { Cognitive Function }\end{array}\end{array}$ & 0.531 & 39.676 & 0.000 & 0.550 & 0.071 & 7.475 \\
B.D & 0.384 & 44.283 & 0.000 & 0.405 & 0.060 & 6.354 \\
Shareholder Value & 0.715 & 57.735 & 0.000 & 0.734 & 0.051 & 14.030 \\
Stakeholder Value & 0.620 & 37.481 & 0.000 & 0.647 & 0.088 & 7.068 \\
\hline
\end{tabular}

The shareholder and stakeholder values of the company are very well explained respectively with an $\mathrm{R}^{2}$ of 0.715 and 0.620 . However, the disciplinary function of the Board and its cognitive function are moderately explained ( $\mathrm{R}^{2}$ equal to 0.531 and 0.384 respectively).

Table 11: Paths coefficients

\begin{tabular}{llcccc}
\hline Dependent Variable & \multicolumn{1}{c}{ Latent Variable } & Value & $\begin{array}{c}\text { Standard } \\
\text { deviation }\end{array}$ & $\mathbf{t}$ & Pr $>|\mathbf{t}|$ \\
\hline Disciplinary Function & Independence B.D & 0.024 & 0.227 & 0.104 & 0.918 \\
B.D & Size B.D & 0.707 & 0.227 & 3.111 & 0.003 \\
Cognitive Function B.D & Bank shareholder & 0.620 & 0.093 & 6.655 & 0.000 \\
\multirow{3}{*}{ Shareholder Value } & Disciplinary Function B.D & 0.109 & 0.112 & 0.972 & 0.335 \\
& Cognitive Function B.D & 0.485 & 0.119 & 4.085 & 0.000 \\
& Debt & 0.394 & 0.074 & 5.298 & 0.000 \\
Stakeholder Value & Disciplinary Function B.D & 0.060 & 0.129 & 0.467 & 0.642 \\
& Cognitive Function B.D & 0.304 & 0.137 & 2.215 & 0.030 \\
& Debt & 0.548 & 0.086 & 6.369 & 0.000 \\
\hline
\end{tabular}

Based on these findings, the disciplinary function of the B.D does not affect shareholder value or stakeholder value of the Tunisian company therefore $\mathrm{H} 1 \mathrm{a}$ and $\mathrm{H} 1 \mathrm{~b}$ hypotheses are rejected. However, the cognitive function of the B.D has a positive and significant impact on shareholder value as well as the stakeholder which brings us to accept $\mathrm{H} 2 \mathrm{a}$ and $\mathrm{H} 2 \mathrm{~b}$ 
hypotheses. In addition, the level of debt has a positive and significant impact on both shareholder and stakeholder values of firms. In fact, the more the value of the company is important, the more the debt increases.

Moreover, the larger the B.D is, the greater the firm ensures the effectiveness of the control exercised by its directors. However, there is no relationship between the presence of outside directors and the disciplinary function of the Board. Beyond the control exercised by the Board, its cognitive function is influenced by the presence of bank shareholders. These encourage the nomination of qualified directors.

In order to study the impact of the age of the directors on the cognitive function, and the impact of dual leadership on the control function, we have treated them separately by using a test of mean difference in SPSS.

For the age of the directors, we divided the sample into firms with $50 \%$ or more of their directors older than 39 years and firms with more than $50 \%$ of their directors have over than 40 years. The following table shows the test results.

Table 12: Test of means difference

\begin{tabular}{lcccc}
\hline & \multicolumn{2}{c}{ Test of Levene on equal } \\
variances & \multicolumn{2}{c}{ Test on equal means } \\
& F & Sig & F & Sig \\
\hline Age - > cognitive function of B.D & 0.056 & 0.813 & 0.149 & 0.532 \\
Duality - -> Disciplinary function of B.D & 3.151 & 0.080 & 0.175 & 0.000 \\
\hline
\end{tabular}

We note that the equal means test for the variable "age of directors" is not significant, so there is a difference in the performance of cognitive function between young administrators and those who are older.

For the variable "duality leader," the equality of means test is significant; we can conclude that there is no difference in the exercise of control between the firms for which the CEO is also chairman of the board and firms that dichotomize between these two functions.

\subsubsection{Global evaluation of models}

The global evaluation of the model is done with the redundancy, the commonality indices and Gof.

Table 13: Global evaluation of models

\begin{tabular}{|c|c|c|c|c|}
\hline & \multicolumn{2}{|c|}{ Measurement Model } & \multicolumn{2}{|c|}{ Structural Model } \\
\hline & Commonalies & Redundancies & Commonalies & Redundancies \\
\hline Disciplinary Function of & 0.681 & 0.361 & 0.679 & 0.362 \\
\hline Cognitive Function of & 0.712 & 0.273 & 0.712 & 0.274 \\
\hline Shareholder value & & 0.715 & & 0.715 \\
\hline Stakeholder value & 0.778 & 0.482 & 0.779 & 0.483 \\
\hline Gof & \multicolumn{2}{|c|}{0.993} & \multicolumn{2}{|c|}{0.991} \\
\hline
\end{tabular}

Commonalities and redundancies Indices are all greater than 0 , which reflects the overall good quality of internal and external models. This positive assessment is also proved by the evidence of Goodness of fit (Gof) associated with the two models since they are very close to1.

\subsubsection{Interpretation of results}

The results of model 1 show that the directors of the Tunisian public limited companies advocate the assistance of the officer, by providing him with advice and opinions rather than discipline by controlling his decisions. This conclusion is consistent with that of Zahra and Pearce (1989) and 
Jhonson et al. (1993) which stressed the importance of service and council roles of the board of directors in the process of firm value creation.

In addition to its role of assisting, the Board of Tunisian firms involved in strategic decisions which corroborates with the theoretical study made by Violina (1999) and with empirical study made by Berghe and Baelden (2005) in the context of French and American firms.

Therefore, in a Tunisian context, the theory of resources dependence outweighs the agency theory which is in contradiction with the results of Black (2001) according to whom governance mechanisms have greater disciplinary effects in emerging countries.

We can explain our finding in favor of the cognitive approach of the board of directors by the fact that most of Tunisian firms are family-owned. Indeed, competent administrators affiliated to the leader seek to improve the cognitive power of their board of directors and assist the manager in decision-making, while those who do not have social relations with the leader do not motivate these roles. Westphal (1999) leads to the same conclusion by showing that administrators are more motivated to help the leaders who know them.

Our study assumes that the debt level affects positively and significantly the value of the company. This conclusion is consistent with the theory of signal (Ross, 1977) according to which the debt is regarded as a signal, given by the head, of the current and future flows of the company. It shows that only efficient firms are willing to bear significant debt because they are able to fulfill their commitments without any problems. This result was also confirmed by Driffield et al. (2007) in the context of Indonesian companies, the performance of these firms increase with the increase in their debt levels. It is still consistent with the hypothesis of substitutability supported by Grossman and Hart (1980), Jensen (1986), Jiraporn and Gleason (2007), Byers et al. (2008) and Monda and Giorgino (2013) postulating the efficiency level of debt as a control mechanism. However, this hypothesis has not been confirmed by Myers (1977) which states that the debt carries high agency costs between shareholders and creditors which will have a negative impact on the value of the firm. Among the traditional characteristics of the board, only its size positively affects the disciplinary role played by the directors of Tunisian firms. Indeed, over the board is large, the more it will need to be able to control and deny, if necessary, decisions taken by the manager. This result is consistent with that found by Kang et al. (2007) in the context of Australian firms.

In addition, by focusing on the cognitive function of the Board of Tunisian firms, we can say that the presence of bankers on the board of directors of a company positively affects the exercise of the director's cognitive role since this type of investor is the most involved in the implementation of the corporate strategy. This result is consistent with studies made by Nileson (2000), Noe et al. (2003) and Güner et al. (2005). This positive effect of the presence of bankers was also detected by Bris et al. (2006), Santos and Rumble (2006) and Barucci and Mattesini (2008) but based on a disciplinary approach. Moreover, our result is in contradiction with that of Smith (2006) which shows that the bank can use its monopoly position to extract profits at the expense of the firm value.

\subsection{Results of Model 2: the Mediator role of the board functions}

We seek to test the mediator role of the board functions (disciplinary and cognitive) on the relationship between the capital of the B.D, formed mainly by the human capital and the relationship capital, and the value of the company. For this, we rely on the approach of Baron and Kenny (1986) which propose to test the following links:

1-The relationship between the antecedent and the consequent

2-The relationship between the antecedent and the potential mediator

3-The relationship between the antecedent and the consequent controlling for the mediator If the relations 1 and 2 are significant and the relation 3 is also, but at the same time the antecedent becomes insignificant, then there are a mediation role. For this, we have developed a model in PLS 
in two stages. We tested the effect of the capital of B.D on the firm value and then, we integrated variables measuring the functions of the Board of Directors.

\subsubsection{Analysis of model 2a}

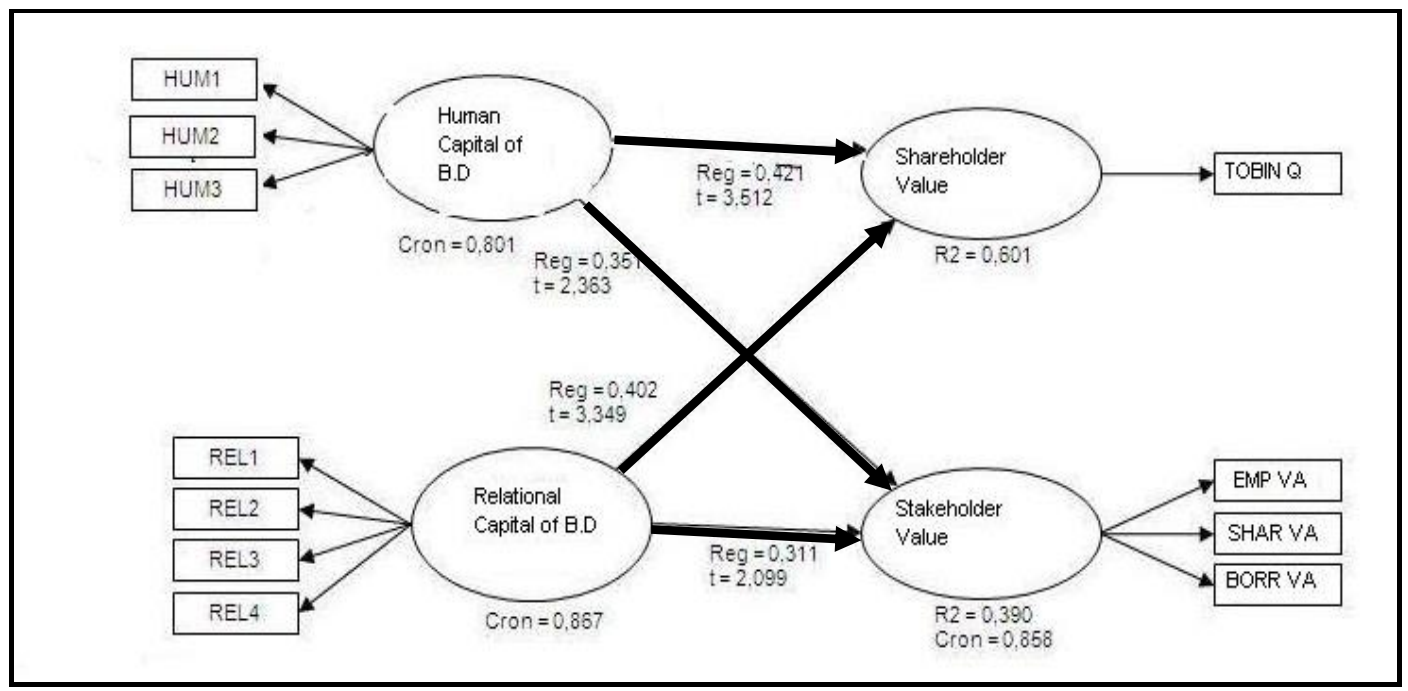

Figure 2: Results of model 2a

We integrated two new latent variables: human capital and relational capital of Board, so before considering the relations between variables, we checked the reliability of measures, the convergent validity and the discriminant validity for these two latent variables.

Table 14: Structural model: Relation between capital of b.d and firm value

\begin{tabular}{lccccc}
\hline Dependent Variable & Latent Variable & Valeur & Ecart-type & $\mathbf{t}$ & $\mathbf{P r}>|\mathbf{t}|$ \\
\hline \multirow{3}{*}{ Shareholder Value } & Human Capital of BD & 0.421 & 0.120 & 3.512 & 0.001 \\
& Relational Capital of BD & 0.402 & 0.120 & 3.349 & 0.001 \\
& $\mathrm{R}^{2}$ & & 0.601 & \\
Stakeholder Value & Human Capital of BD & 0.351 & 0.148 & 2.363 & 0.021 \\
& Relational Capital of BD & 0.311 & 0.148 & 2.099 & 0.039 \\
& $\mathrm{R}^{2}$ & \multicolumn{4}{c}{0.390} \\
\hline
\end{tabular}

The capital of BD (human and relational) positively and significantly affects both shareholder and stakeholder value of Tunisian firms. This confirms the relationship 1. However, the explanatory power of shareholder value $\left(R^{2}=0.601\right)$ is greater than that of the stakeholder value $\left(R^{2}=0.390\right)$. 


\subsubsection{Analysis of model $2 b$}

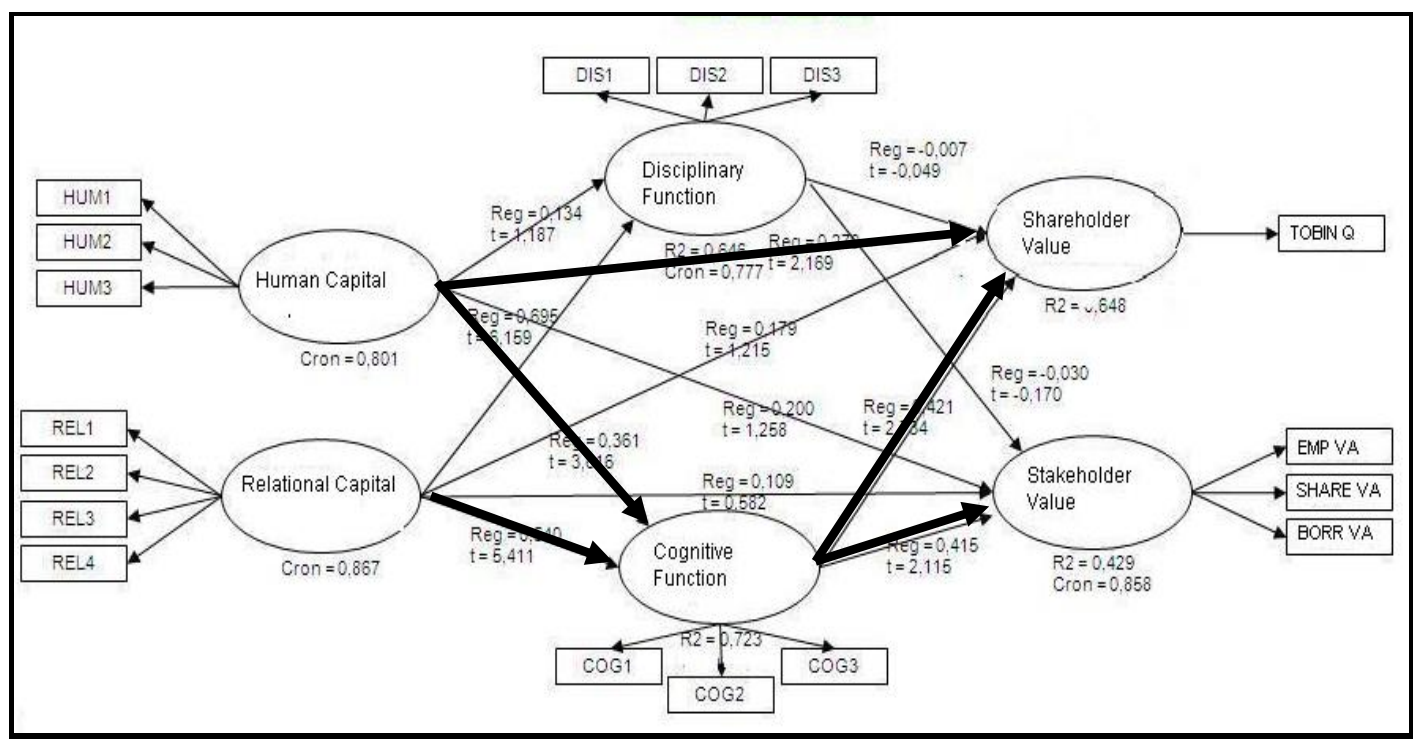

Figure 3: Results of model 2b

To verify the relation 2, we study the impact of the Board's Capital on its functions. The results show that the relationship between the social capital and the board functions (disciplinary and cognitive) is positive and significant (respectively $\operatorname{Reg}=0.695, \mathrm{t}=6.195$ and $\mathrm{Reg}=0.540, \mathrm{t}=$ 5.411). Similarly, for the effect of human capital on the cognitive function $(\operatorname{Reg}=0.361, t=3.518)$. However, its impact is not significant on the disciplinary function of the Board.

Regarding the relationship 3, we get the following results

\section{Table 15: Mediator Effect of cognitive function of BD}

\begin{tabular}{lccccc}
\hline Model 2b & Reg & Sig(t) & Reg & Sig(t) \\
\hline $\begin{array}{l}\text { Human Capital } \rightarrow \\
\text { Shareholder Value }\end{array}$ & 0.270 & 2.169 & $\begin{array}{c}\text { Cognitive Function } \rightarrow \\
\text { Shareholder Value }\end{array}$ & 0.421 & 2.734 \\
$\begin{array}{l}\text { Relational Capital } \rightarrow \\
\text { Shareholder Value }\end{array}$ & 0.179 & 1.215 & & & \\
$\begin{array}{l}\text { Human Capital } \rightarrow \\
\text { Stakeholder Value }\end{array}$ & 0.200 & 1.258 & $\begin{array}{c}\text { Cognitive Function } \rightarrow \\
\text { Stakeholder Value }\end{array}$ & 0.415 & 2.115 \\
$\begin{array}{l}\text { Relational Capital } \rightarrow \\
\text { Stakeholder Value }\end{array}$ & 0.109 & 0.582 & talu & & \\
\hline
\end{tabular}

Note that we have not studied the mediating role of the disciplinary function of the relationship between capital and the value of the company since this function has no direct effect on the value of company (see Figure 1). Moreover, the relation 2 is not checked for the impact of human capital on disciplinary function of the Board. So H3 is not tested.

From Table 15, we conclude that:

The cognitive function of B.D plays a mediating role in the relationship between human capital and relational capital of administrators on the one hand and the value of Tunisian companies on the other hand.

The cognitive function of B.D has a direct impact on shareholder value of Tunisian firm. This function plays a full mediating role in the relationship between human capital and stakeholder value. $\mathrm{H} 2 \mathrm{~b}$ and $\mathrm{H} 4 \mathrm{~b}$ are validated. It has also a mediating role on the relationship between human capital and shareholder value. However, this mediation is not complete (the direct relationship between 
human capital and shareholder value remains significant) that means there are, may be, other mediating factors. $\mathrm{H} 2 \mathrm{a}$ and $\mathrm{H} 4 \mathrm{a}$ are validated. Already, the studies made by Carpenter and Westphal (2001), Golden and Zajac (2001) and Jhonson et al. (2013) were conducted in this direction by emphasizing the role of skills and external relationship of the board of directors in the reliability of advice and opinions provided by these directors. This assistance has a positive impact on the value of the company relative to both shareholders and other stakeholders.

Although they found the same results for the indirect effect of human capital on the firm value, Sicilianon (1996), Beekun et al. (1998) and Xie et al. (2003) were based on the intermediation of the disciplinary function of the Board and not the cognitive function to demonstrate this relationship.

Cognitive function has a complete mediating effect on the relationship between social capital and shareholder and stakeholder value. $\mathrm{H} 2 \mathrm{a}, \mathrm{H} 2 \mathrm{~b}, \mathrm{H} 4 \mathrm{c}$ and $\mathrm{H} 4 \mathrm{~d}$ are validated. Thus, expanding connections of administrators allow them to benefit from a host of new innovative and creative ideas that leads to creating a competitive advantage. The work of Westphal (1999) was made in this direction and has the same result in the context of American industrial firms. Similarly, the work of Ben Hadj M'barek (2005), in a French context, confirms this conclusion and shows that the larger the administrator's network is, the easier its managers' access to information on growth opportunities. However, Ferris et al. (2003) found no significant relationship between the networks of directors and firm performance. Jiraporn et al. (2008) and Jackling and Johl (2009) lead to a negative effect of mediation of the disciplinary function on the relationship between the network of directors and firm performance. According to these authors, administrators make connections so busy that they cannot exercise their oversight role effectively.

\section{CONCLUSION}

In this research we have analyzed the effects of the director's skills and networks on shareholder value as well as stakeholder value of Tunisian companies.

This relationship has been studied taking into account the mediating role of cognitive function of the Board. Some variables related to individual characteristics of the BD (age directors, duality, BD independence), and others related to the company and its ownership structure (debt and shareholders bankers) were included in the model. The results assume that in accordance with cognitive theory, boards of Tunisian firms have a second strategic function favoring participation in strategic decisionmaking and the provision of advice. The consideration of this new role calls into question the effectiveness of the control by the directors. Indeed, if the cognitive function of the BD has a mediating role between the capital and the value of the company, the disciplinary function has neither direct impact nor mediating one on the value of the firm which is in contradiction with the agency theory.

Consequently, the role of the Board of Tunisian firms is no longer limited to the reduction of informational asymmetry with its independence and its large size but it should stress the cognitive contribution through human and relational skills of its members, to improve the value of their business.

Source of Funding: To conduct this research, author(s) bore all expenses by his/her/their own.

Views and opinions expressed in this study are the views and opinions of the authors, Asian Journal of Empirical Research shall not be responsible or answerable for any loss, damage or liability etc. caused in relation to/arising out of the use of the content. 


\section{References}

Abor, J., \& Biepke, N. (2006). Does board caracteristics affect the capital structure decisions of Ghanian firms. Corporate Ownership and Control, 4(1), 113-118.

Albouy, M. (1999). Theory, application and limitations of measuring value creation. French Review of Management, 122, 81-90.

Anderson, R. C., \& Reeb, D. M. (2004). Board composition, balancing family influence in S \& P 500 firms. Administrative Science Quaterly, 49, 209-237.

Arrègle, J. L., Durand, R., \& Very, P. (2004). Origins of social capital and competitive advantages of family firms. Management, 7(2), 13-36.

Baron, R. M., \& Kenny, D. A. (1986). The moderator-mediator variable distinction in social psychological research, conceptual, strategic and statistical consideration. Journal of Personality and Social Psycology, 51, 1173-1182.

Barucci, E., \& Mattesini, F. (2008). Bank shareholding and lending: Complementarily or substitution? Some evidence from a panel of large Italian firms. Journal of Banking and Finance, 32(10), 2237-2247.

Beekun, R. I., Stedham, Y., \& Young, G. J. (1998). Board characteristics, managerial controls and corporate strategy: A study of US hospitals. Journal of Management, 24, 3-19.

Black, B. (2001). The corporate governance behavior and market value of Russian firms. Emerging Market Review, 2, 89-108.

Black, B., Hasung J., \& Woochan K. (2006). Does corporate governance affect firms' market values? Evidence from Korea. Journal of Law, Economics and Organization, 22, 366-413.

Ben Hadj M'Barek, K. (2005). Influence of network administrators on the strategy of the firm: Application to the framework of strategic partnerships. $\mathrm{PhD}$ in Management Science, University of Burgundy.

Berghe, V., \& Baelden, T. (2005). The monitoring role of the board: One approach does not fit all. Journal of Corporate Governance, 13(5), 680-690.

Berger, P. G., Ofek, E., \& Yermarck, D. (1997). Managerial entrenchment and capital structure decisions. Journal of Finance, 52(4), 1411-1438.

Bodaghi, A., \& Ahmadpour, A. (2010). The effect of corporate governance and ownership structure on capital structure of Iranian listed companies. $7^{\text {th }}$ International Conference on enterprise system Accounting and Logistics, Island, Greece.

Bris, A., Welch, I., \& Zhu, N. (2006). The Cost of Bankruptcy. Journal of Finance, 56(2), 12531303.

Brown, L. D., \& Caylor, M. L. (2006). Corporate governance and firm valuation. Journal of Accounting and Public Policy, 25, 409-434.

Byers, S. S., Field, L. P., \& Fraser, D. R. (2008). Are corporate governance and bank monitoring substitutes: Evidence from the perceived value of bank loans. Journal of Corporate Finance, 14(4), 475-483.

Carpenter, M. A., \& Westphal J. D. (2001). The strategic context of external network ties examining the impact of director appointments on board involvement in strategic decisions making. Academy of Management Journal, 44, 633-660.

Carter, D. A., Simkins, B. J., \& Simpson, W. G. (2003). Corporate governance, board diversity and firm value. The Financial Review, 38, 33-53.

Charreaux, G. (1997). The public company is it necessarily less efficient. French Management Review, September-October, 38-55.

Charreaux, G. (2000). The board of directors in the governance theories. Financial Review, 127, 817.

Charreaux, G. (2002). Which theory for governance? Shareholder governance cognitive governance. FARGO research paper.

Driffield, N., Mahambar, V., \& Pal, S. (2007). How does ownership structure affect capital structure and firm value. Economics of Transition, 15(3), 535-573.

ElGaied, M., \& Rachdi, H. (2008). The impact of Independence and the duality of the Board of Directors on business performance: Application to the US context. Lebanese Magazine of Business and Economics, No.3. 
Ferris, S. P., Jagannathan, M., \& Pritchard, A. C. (2003). Too busy to mind the business? Monitoring by directors with multiple board appointments. Journal of Finance, 58, 1087-1111.

Fosberg, R. (1989). Outside directors and managerial monitoring. Akron Business and Economics Review, 20(2), 24-32.

Ghaya, H., \& Lambert, G. (2010). Cognitive specificities of boards and corporate performance: an empirical study on the CAC 40 companies. "Working Paper No. 2010-24, University of Strasbourg.

Golden, B. R., \& Zajac, E. (2001). When will boards influence strategies: Inclination x power = Strategic Change. Management Journal, 22, 1087-1111.

Güner, A. B., Malmendier, U., \& Tate, G. (2005). The impact of board with financial expertise on corporate policies. NBER Working Papers, 11914.

Grossman, S. J., \& Hart, O. D. (1980). Takeover bids, the free rider problem, and the theory of the corporation. Bell Journal of Economics, 11, 42-64.

Heng, T. B., \& Azrabajani, S. (2012). Board of directors and capital structure: Evidence from leading Malaysian companies. Easian Social Science, 8(3), 123-136.

Hillman, A. J., \& Dalziel, T. (2003). Board of directors and firm performance: Integrating agency and resource dependence perspectives. Academy Management Review, 28(3), 383-396.

Ioannis, G. (2009). Board of directors and firm performance: A combination of agency and dependence theory perspective. BBS Doctoral symposium.

Jackling, B., \& Johl, S. (2009). Board structure and firm performance: Evidence from India's top companies. Corporate Governance: An international Review, 17(4), 492-509.

Jeanjean, T., \& Stolowy, H. (2006). Analysis of determinants of financial competence of boards in France. Presentation at the Joint Meeting of the Academy of Sciences and Accounting and Financial Techniques and the French Institute of Directors, Mars, 2006.

Jensen, M. (1986). Agency cost of free cash flow, corporate finance and takeovers. American Economic Review, 76(2), 323-329.

Jensen, M., \& Meckling, W. (1976). Theory of the firm: Managerial behavior, Agency cost and ownership structure. Journal of Financial Economics, 3, 305-360.

Jiraporn, P., \& Gleason, K. C. (2007). Capital structure, shareholder rights and corporate governance. Journal of Financial Research, 30(1), 21-33.

Jiraporn, P., Kim, Y. S., \& Davidson, W. N., (2008). Multiple directorships and corporate diversification. Journal of Empirical Finance, 15, 418-435.

Jhonson, R. A., Hosskisson, R. E., \& Hitt, M. A. (1993). Board of directors involvement in restructuring: The effect of board versus managerial controls and characteristics. Strategic Management Journal, 14, 33-50.

Jhonson, S., Schnatcerly, K., \& Hitt A. (2013). Board composition beyond independence: Social capital, human capital and demographics. Journal of Management, 39(1), 232-262.

Kang, J. K., Cheng, M., \& Gray, S. J. (2007). Corporate governance and board composition: diversity and independence of Australian boards. Corporate Governance, 15(2), 194-207.

Karoui, L., \& Khlif, W. (2010). Traditional determinants of performance of boards were they still make sense in SMEs: An exploratory study in the French context. hall, No. 00460409, 1st version.

Korn, F. (1999). Survey of corporate governance. New York.

Kowalwiski, O. (2012). Does Corporate Governance Determine Corporate Performance and Dividends During Financial Crisis: Evidence from Poland. Working Paper, University of Kosminski.

Kula, V. (2005). The impact of the roles, structure and process of board on firm performance: evidence from Turkey. Corporate Governance, 13(2), 265-276.

Lemmon, M., \& Lins, K. (2003). Ownership structure, corporate governance, and firm value: Evidence from the East Asian financial crisis. The Journal of Finance, 58, 1455-1468.

Lipton, M., \& Lorsh, J. W. (1992). A modest proposal for improved corporate governance. Business Lawyer, 59, 59-77.

Mc Fadyen, A. (2003). What do we know about the impact of interpersonal exchange networks on the knowledge creation hrocess? http//cims.ncsu.edu: 8080/documents/interpersonalnetwork.pdf. 
Mitton, T. (2002). A cross-firm analysis of the impact of corporate governance on the East Asian financial crisis. Journal of Financial Economics, 64, 215-241.

Monda, B., \& Giorgino, M. (2013). Corporate Governance and shareholder value in listed firms: An empirical analysis in five countries (France, Italy, Japan, UK, USA). Working Paper, Polytechnique de Milano.

Myers, C. (1977). Determinants of corporate borrowing. Journal of Financial Economics, 5, 147175.

Nileson, J. D. (2000). The role of institutional investors in corporate governance. Working Paper.

Noe, T. H., Rebello, M. J., \& Wang, J., (2003). Corporate financing: An artificial agent-based analysis. Journal of Finance, 8(3), 943-973.

Ong, C. H., \& Wan, D. (2005). Board structure, process and performance: Evidence from public listed companies in Singapore. Corporate Governance, 13(2), 277-290.

Penrose, E. (1959). The theory of the growth of the firm. Oxford Basic Blackwell.

Pfeffer, J., \& Salancik, (1978). The external control of organization: A resource dependence perspective. Harper and Row.

Poulain, R. (2006). The shareholding of employees in France: The value creation factor. Working Paper, University of Montesquieu.

Rindova, V., \& Fombrun, C. (1999). Constructing competitive advantage: The role of firm constituent interactions. Strategic Management Journal, 20, 691-710.

Rosenstein, S., \& Wyatt, J. (1997). Inside directors, board effectiveness and shareholders wealth. Journal of Financial Economics, 44, 229-250.

Ross, L. (1977). The intuitive psychologist and his shortcomings: Distortions in the attribution process. In L. Berkowitz (Ed.), Advances in experimental social psychology, 10, New York: Academic Press.

Santos, J., \& Rumble, A. S. (2006). The American keiretsu and universal banks: investing, voting and sitting on non-financials corporate boards. Journal of Financial Economics, 80, 419454.

Sicilianon, J. I. (1996). The relationship of board member diversity to organizational performance. Journal of Business Ethics, 15, 1313-1320.

Smith, J. M. (2006). Should banks own equity stakes in their borrowers? A contractual solution to hold up problems. Journal of Banking and Finance, 30, 2911-2929.

Suhaila, M. K., \& Mahmood, W. (2008). Capital structure and firm characteristics: Some evidence from Malaysian companies. MPRA working paper, 14616.

Thiétart, R. A., (1999). Validity and reliability of the research. Research Methods in Management, Thiétart edition, Dunod, Paris.

Violina, R. (1999). What corporate boards have to do with strategy. Journal of Management Studies, $36,7,953-975$.

Walt, C., \& Ingley, N. (2003). Board dynamics and the influence of professional background, gender and ethnic diversity of directors. Corporate Governance, 11(3), 218-233.

Westphal, J. D. (1999). Collaboration in the boardroom behavioural and performance consequences of CEO-board social ties. Academy of Management Journal, 171-180.

Xie, B., Davidson, W. N., \& Dadalt, P. J. (2003). Earnings management and corporate governance: The roles of the board and the audit committee. Journal of Corporate Finance, 9, 295-316.

Zahra, S., \& Pearce J. (1989). Board of directors and corporate financial performance: A review and integrative model. Journal of Management, 15(2), 291-334. 